\author{
International \\ Journal of Thy hical \\ dication \\ DOI : 10.15740/HAS/IJPE/9.1\&2/1-4 \\ e ISSN-0976-7924 Visit us : www.researchjournal.co.in \\ Research Paper
}

Volume 9 | Issue $1 \& 2$ | April \& October, 2016| 1-4

\title{
Humidity influences exercise capacity in subjects with Exercise- Induced Broncho - Constriction (EIB)
}

\section{KIRAN CHAKRAVARTHI}

Received : 25.03.2016; Revised : 01.09.2016; Accepted : 15.09 .2016

Author for correspondence
C. KIRAN CHAKRAVARTHI
Department of Physical Education and
Sports Sciences, Sri Krishnadevaraya
University, ANANTAPURAM (A.P.)
INDIA
Email: kiranchakravarthi9@ gmail.com

\section{-ABSTRACT}

The primary aim of the present study was to examine the effect of changing the humidity of the environmental air upon exercise capacity measured by peak oxygen uptake $\left(\mathrm{V}^{\bullet} \mathrm{O}_{2 \text { peak }}\right)$, peak ventilation $\left(\mathrm{V}^{\bullet} \mathrm{E}_{\text {peak }}\right)$ and peak running speed $\left(\mathrm{V}^{\bullet}\right.$ peak $)$ and secondarily to assess the influence of environmental humidity upon EIB in subjects suffering from EIB. Twenty subjects (10-45 years old, male/female:13/7) with diagnosed EIB performed exercise testing under standardised, regular environmental conditions, $20.2^{\circ} \mathrm{C}( \pm 1.1)$ and 40 per cent $( \pm 3.3)$ relative humidity [mean $( \pm$ sd)] and under standardised humid environmental conditions, $19.9^{\circ} \mathrm{C}( \pm 1.0)$ and 95 per cent $( \pm 1.7)$ relative humidity in random order on separate days. Lung function was measured before and 1, 3, 6, 10 and $15 \mathrm{~min}$ after exercise. Heart rate (HR), oxygen uptake $\left(\mathrm{V}^{\bullet} \mathrm{O}_{2}\right)$, respiratory gas exchange ratio (RER), breathing frequency $(\mathrm{BF})$ and minute ventilation $\left(\mathrm{V}^{*} \mathrm{E}\right)$ were measured during exercise. The results were indentified that $\mathrm{V}^{\bullet} \mathrm{O}_{2 \text { peak }}$ and $\mathrm{V}_{\text {peak }}^{\cdot}$ increased significantly from 40 per cent to 95 per cent relative humidity of the environmental air, 4.5 per cent and 5.9 per cent, respectively $(\mathrm{P}=0.001)$. $\mathrm{HR}_{\text {peak }}$ increased significantly in the humid environment, while $\mathrm{BF}_{\text {peak }}$ decreased significantly. The conclusion that exercises capacity $\left(\mathrm{V}^{\bullet} \mathrm{O}_{2 \text { peak }}\right.$ and $\mathrm{V}^{\cdot}$ peak $)$ markedly improved during exercise in humid air in subjects with EIB, whereas EIB was reduced to the half.

- KEY WORDS : Peak oxygen uptake, Exercise capacity, Environmental humidity, Exerciseinduced broncho-constriction

- HOW TO CITE THIS PAPER : Chakravarthi, C. Kiran (2016). Humidity influences exercise capacity in subjects with Exercise-Induced Broncho - Constriction (EIB). Internat. J. Phy. Edu., 9 (1\&2) : 1-4, DOI : 10.15740/HAS/IJPE/9.1\&2/1-4. 